\title{
PEMODELAN MATEMATIKA DENGAN METODE RUNGE KUTTA UNTUK PENYAKIT CAMPAK MENGGUNAKAN MATLAB R2010a
}

\author{
Ketut Queena Fredlina ${ }^{1)}$ Komang Tri Werthi $^{2)}$ \\ Program Studi Teknik Informatika ${ }^{1)}$ \\ Program Studi Sistem Informasi Akuntansi ${ }^{2}$ \\ STMIK Primakara, Denpasar, Bali ${ }^{1)}$ 2) \\ naa.queena@gmail.com ${ }^{1)}$ komang.triwerthi@gmail.com ${ }^{2)}$
}

\begin{abstract}
Mathematical models have important roles in various fields of science. By using several assumptions, problems that exist in the living environment can be transformed in mathematical models. From the existing mathematical model, the parameters that affect the model can then be analyzed. An epidemic is an event that can be transformed into a mathematical model. Epidemic events are the occurrence of the spread or outbreak of an illness in a region. Measles is one of the causes of death in developing countries caused by the measles virus, the Paramixovirus group. In 1982 a measles immunization program in Indonesia was conducted. Based on data from the 2015 Ministry of Health, Indonesia has a medium immunization coverage in Southeast Asia, which is 84\%. In 2020 Indonesia has a target rate of measles immunization coverage of $95 \%$. Measles is a concern of the Bali Provincial Health Office because the spread of this disease is always high. Specifically in this study we will discuss mathematical models for the incidence of measles epidemics. The problem is how to construct the model and what parameters are the most significant influences in the mathematical model of measles. In making mathematical models for the spread of measles, the population is divided into 3 parts: Susceptible, Infectious, and Recovered. Furthermore, analyze the parameters and determine the basic reproduction ratio $\left(\boldsymbol{R}_{\mathbf{0}}\right)$, then numerical simulations were carried out using the Order 4 Runge Kutta method.
\end{abstract}

Keywords : Mathematics, Measles, basic reproduction ratio $\left(\boldsymbol{R}_{\mathbf{0}}\right)$, Runge-Kutta Methods

\begin{abstract}
ABSTRAK
Model matematika memiliki peran yang cukup penting dalam berbagai bidang ilmu. Dengan menggunakan beberapa asumsi, permasalahan yang ada dalam lingkungan kehidupan dapat ditransformasikan dalam model matematika. Dari model matematika yang ada selanjutnya dapat dianalisis parameter-parameter yang mempengaruhi model tersebut. Kejadian epidemi merupakan salah satu kejadian yang dapat ditransformasikan dalam model matematika. Kejadian epidemi adalah kejadian penyebaran atau mewabahnya suatu penyakit dalam suatu wilayah. Penyakit campak merupakan salah satu penyakit penyebab kematian penduduk di negara-negara berkembang yang disebabkan oleh virus campak golongan Paramixovirus. Pada tahun 1982 program imunisasi campak di Indonesia telah dilakukan. Berdasarkan data dari Departemen Kesehatan 2015, Indonesia memiliki cakupan imunisasi kategori sedang di Asia Tenggara yakni 84\%. Pada tahun 2020 Indonesia memiliki target angka cakupan imunisasi campak sebesar 95\%. Penyakit campak menjadi perhatian Dinas Kesehatan Profinsi Bali karena penyebaran penyakit ini selalu ada. Secara khusus dalam penelitian ini akan membahas model matematika untuk kejadian epidemi penyakit campak. Yang menjadi permasalahan adalah bagaimana mengontruksi model dan parameter apakah yang berpengaruh paling signifikan dalam model matematika penyakit campak. Dalam pembuatan model matematika untuk penyebaran penyakit campak, populasi manusia dibagi menjadi 3 bagian yaitu : Susceptible, Infectious, dan Recovered. Selanjutnya menganalisis parameter dan menentukan nilai basic reproduction ratio $\left(R_{0}\right)$, kemudian dilakukan simulasi numerik dengan metode Runge Kutta Orde 4.
\end{abstract}

Kata kunci : model matematika, campak, basic reproduction ratio $\left(\boldsymbol{R}_{\mathbf{0}}\right)$,metode Runge-Kutta 


\section{Pendahuluan}

Penyakit campak merupakan salah satu penyakit penyebab kematian penduduk di negara-negara berkembang yang disebabkan oleh virus campak golongan Paramixovirus. Lima belas persen kematian akibat campak di Asia tahun 2002 terjadi di Indonesia. Penularan terjadi melalui percikan ludah dari hidung, mulut maupun tenggorokan penderita campak. Penyakit ini dapat menyerang siapa saja tanpa mengenal usia dan jenis kelamin.

Model matematika memiliki peran cukup penting dalam berbagai bidang ilmu. Dengan menggunakan beberapa asumsi, permasalahan yang ada dalam lingkungan kehidupan dapat ditransformasikan dalam model matematika. Dari model matematika yang ada selanjutnya dapat dianalisis parameter-parameter yang mempengaruhi model tersebut.

Kejadian epidemi merupakan salah satu kejadian yang dapat ditransformasikan dalam model matematika. Kejadian epidemi adalah kejadian penyebaran atau mewabahnya suatu penyakit dalam suatu wilayah. Secara khusus dalam penelitian ini akan membahas model matematika untuk kejadian epidemi penyakit campak.

Dalam pembuatan model matematika untuk penyebaran penyakit campak, populasi manusia dibagi menjadi 3 bagian yaitu : sub populasi Susceptible adalah sub populasi yang rentan terhadap penyakit campak, sub populasi Infectious adalah sub populasi yang terinfeksi dan menularkan campak, dan sub populasi Recovered adalah sub populasi yang telah sembuh.

Model yang disusun adalah model matematika dengan bentuk sistem persamaan diferensial yang bergantung pada variabel-variabel yang meyatakan tiap-tiap populasi. Selanjutnya dilakukan analisis parameter dan mencari basic reproduction ratio $\left(R_{0}\right)$ dan untuk simulasi numerik dengan metode Runge Kutta Orde 4.

Tujuan dalam penelitian ini adalah mengetahui cara mengontruksi model penyebaran penyakit campak dan mengetahui parameter mana yang berpengaruh paling signifikan dalam model penyebaran penyakit campak. Manfaat dari pembuatan model matematika penyebaran penyakit campak dapat memberikan gambaran tentang dinamika penyakit endemic campak sehingga dapat membantu pemerintah dalam pengambilan kebijakan bidang kesehatan.

\section{Metodologi Penelitian}

\section{Sumber Penelitian}

Penelitian ini dilakukan dengan menggunakan metode penelitian kepustakaan atau studi literatur. Hal ini dilakukan untuk mendalami, mencermati, menelaah, dan mengidentifikasi pengetahuan yang menunjang penelitian ini. Sumber-sumber yang digunakan dapat berupa buku, jurnal penelitian, skripsi, tesis, maupun internet.

\section{Waktu dan Lokasi Penelitian}

Penelitian ini akan dilaksanakan selama delapan (8) bulan, mulai pada Juni 2017 sampai Februari 2018. Penelitian dilakukan di Denpasar dan simulasi model akan dilakukan pada Laboratorium di STMIK Primakara.

\section{Pembentukan Model}

Adapun langkah-langkah dalam pembentukan model matematika penyebaran penyakit campak adalah:

1. Identifikasi Masalah,

2. Membuat Asumsi.

3. Menyelesaikan dan Menginterpretasikan Model.

4. Verifikasi Model

\section{HASIl DAN PEMbahasan}

\section{Pembentukan Model}

Dalam model ini, populasi $(N)$ dibagi menjadi 3 sub populasi, yaitu: Susceptible $(S(t))$ menyatakan jumlah individu yang rentan terhadap penyakit campak, Infectious $(I(t))$ menyatakan jumlah individu yang telah terinfeksi campak dan Recovered $(R(t))$ menyatakan individu yang telah sembuh dari penyakit campak. Untuk selanjutnya untuk penyederhanaan akan ditulis $S, I$, dan $R$.

Populasi $S$ akan bertambah karena adanya kelahiran sebesar $\Pi$, dimana nilai $\Pi$ adalah konstan. Populasi $S$ akan berkurang karena adanya kematian sebesar $\mu$. Selain itu, apabila $S$ berinteraksi dengan individu yang sedang terinveksi, ini menyebabkan tertularnya populasi $S$ sebesar $x$ dan akan masuk kedalam populasi $I$.

Populasi $I$ akan berkurang apabila adanya kematian karena faktor lain sebesar $\mu$ dan kematian karena penyakit campak sebesar $\mu_{c}$. Selain itu populasi ini juga dapat berkurang 
karena penderita campak dapat sembuh dengan laju $y$.

Populasi $R$ diasumsikan tidak dapat kambuh menjadi penderita penyakit campak, sehingga berkurangnya populasi ini disebabkan oleh kematian secara alam dengan laju $\mu$.

Total populasi dinotasikan dengan $N$ dimana $N=S+I+R$, sedangkan $\frac{1}{N}$ merupakan proporsi populasi yang terinfeksi penyakit campak.

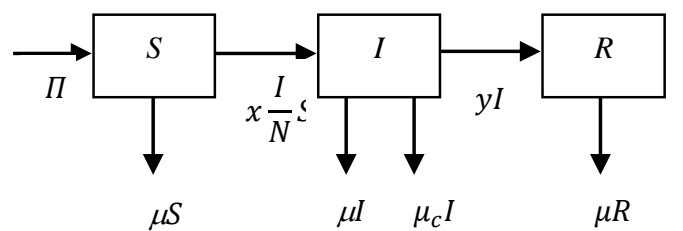

Gambar 1. Diagram Alir Model Matematika Penyakit Campak

\section{Analisis Model}

Untuk menganalisis parameter pada model matematika yang telah dibentuk, hal pertama yang perlu dilakukan adalah mencari titik kritis dan nilai eigen kemudian dilanjutkan dengan basic reproduction ratio $\left(R_{0}\right)$.

\section{Titik Kritis}

Dalam mencari titik kritis, model dibuat dalam posisi konstan terhadap waktu, yaitu:

$$
\begin{aligned}
& \frac{d S}{d t}=-x \frac{I}{N} S-\mu S+\Pi=0 \\
& \frac{d I}{d t}=x \frac{I}{N} S-\left(\mu+\mu_{t}+y\right) I=0 \\
& \frac{d R}{d t}=y I-\mu R=0
\end{aligned}
$$

Dengan menggunakan program

Maple, diperoleh dua titik kritis yaitu:

1) $\left(S=\frac{\Pi}{\mu}, I=0, R=0\right)$, yang berarti seluruh populasi sehat dan tidak ada yang terkena penyakit campak. Titik kritis ini merupakan kondisi yang diharapkan terjadi pada kehidupan nyata.

2) $\left(S=\frac{(\mu+y) \Pi}{\mu\left(x-\mu_{t}\right)}, I=\frac{\Pi\left(x-\mu-\mu_{t}-y\right)}{\left(\mu+\mu_{t}+y\right)\left(x-\mu_{t}\right)}, R=\right.$ $\left.\frac{y \Pi\left(x-\mu-\mu_{t}-y\right)}{\mu\left(\mu+\mu_{t}+y\right)\left(x-\mu_{t}\right)}\right)$, titik kritis yang kedua berarti setiap populasi $S, I$, maupun $R$ memiliki jumlah populasi tertentu. Hal ini bukan kondisi yang diaharapkan karena masih terdapat populasi yang terkena penyakit campak.
Titik kritis menggambarkan jumlah populasi manusia yang dituju. Dalam kehidupan nyata, jumlah populasi manusia tidak mungkin negatif, oleh karena itu titik kritis yang kedua harus diberi syarat agar bernilai positif. Perlu diperhatikan nilai $x-$ $\mu-\mu_{t}-y$, agar bernilai positif maka $x>$ $\mu+\mu_{t}+y$. Apabila syarat tersebut terpenuhi, nila dari $x-\mu_{t}$ akan bernilai positif juga.

\section{Nilai Eigen}

Nilai Eigen berfungsi untuk mengetahui kestabilan dari suatu sistem. Untuk mencari nilai eigen, hal pertama yang perlu dilakukan adalah mencari matriks Jacobian ( $M J)$. Matriks Jacobian dari model yang terbentuk adalah:

$$
M J=\left[\begin{array}{lll}
\frac{\partial S}{\partial S} & \frac{\partial S}{\partial I} & \frac{\partial S}{\partial R} \\
\frac{\partial I}{\partial S} & \frac{\partial I}{\partial I} & \frac{\partial I}{\partial R} \\
\frac{\partial R}{\partial S} & \frac{\partial R}{\partial I} & \frac{d R}{\partial R}
\end{array}\right]
$$

MJ

Sehingga diperoleh:

$$
=\left[\begin{array}{ccc}
-\frac{x I}{N}+\frac{x S I}{N^{2}}-\mu & -\frac{x S}{N}+\frac{x S I}{N^{2}} & \frac{x S I}{N^{2}} \\
\frac{x I}{N}-\frac{x S I}{N^{2}} & \frac{x S}{N}-\frac{x S I}{N^{2}}-\mu-\mu_{t}-c & -\frac{x S I}{N^{2}} \\
0 & c & -\mu
\end{array}\right]
$$

Substitusikan titik kritis yang telah didapat ke dalam $M J$, dengan demikian akan diperoleh dua matriks Jacobian.

Untuk titik kritis (1), $M J$ yg diperoleh adalah:

$M J=\left[\begin{array}{ccc}-\mu & -x & 0 \\ 0 & x-\mu-\mu_{t}-y & 0 \\ 0 & c & -\mu\end{array}\right]$

Dengan mengetahui matriks Jacobian, nilai eigen dapat dicari dengan:

$\operatorname{det}(M J-\lambda I)=0$

Dengan demikian diperoleh $\lambda$ atau nilai eigen untuk titik kritis (1) adalah:

$\lambda_{1}=-\mu, \quad \lambda_{2}=-\mu$,

$$
\lambda_{3}=x-\mu-\mu_{t}-y .
$$

Dengan cara yang sama, dapat ditemukan matriks jacobian untuk titik kritis (2), sehingga diperoleh nilai eigen untuk titik kritis (2) yaitu:

$$
\begin{aligned}
& \lambda_{1}=-\mu, \lambda_{2} \\
& =\frac{-B+\sqrt{B^{2}-4 A C}}{2 A}, \quad \lambda_{3} \\
& =\frac{-B-\sqrt{B^{2}-4 A C}}{2 A}
\end{aligned}
$$


Dengan:

$$
\begin{aligned}
& A=x J, \\
& B=x\left(\mu_{t} \mu-x\right), \\
& C=\mu M K L . \\
& J=\mu+y, \\
& K=x-\mu_{t}, \\
& L=x-\mu-\mu_{t}-y, \\
& M=\mu+\mu_{t}+y .
\end{aligned}
$$

Suatu sistem dikatakan stabil apabila semua nilai eigen dari sistem tersebut bernilai negatif atau $\lambda_{i}<0$ dengan $i=1,2$, dan 3. Nilai eigen (4.2) akan stabil dan menuju titik kritis $\left(S=\frac{\Pi}{\mu}, I=0, R=0\right)$ apabila $L<0$ atau $x<\mu+\mu_{t}+y$. Hal ini akan bertentangan dengan syarat untuk titik kritis (2). Ini menyebabkan populasi $I$ dan $R$ akan bernilai negatif, dalam halnya kehidupan nyata tidak mungkin terjadi kondisi seperti ini maka titik kritis (2) dapat diabaikan. Dapat dikatakan titik kritis (2) akan ada dan stabil apabila nilai eigen (4.1) tidak stabil.

Untuk membuat nilai eigen (4.2) stabil, ketiga nilai eigen harus negatif. Nilai dari $\lambda_{1}$ sudah negatif, sehingga nilai dari $\lambda_{2}$ dan $\lambda_{3}$ perlu diberi syarat agar bernilai negatif juga.

Nilai $A=x J$ pasti positif, sehingga penyebut dari nilai eigen pasti positif. Oleh karena itu pembilang harus bernilai negatif.

$$
\begin{aligned}
-B+\sqrt{B^{2}-4 A C} & <0 \\
\sqrt{B^{2}-4 A C} & <B \\
B^{2}-4 A C & <B^{2} \\
-4 A C & <0 \\
A C & >0
\end{aligned}
$$

Karena $A$ pasti positif maka $C$ haruslah juga bernilai positif agar $A C>0$. Selain itu $B$ juga harus bernilai positif, karena jika tidak nilai eigen akan bernilai positif dan menjadi tidak stabil.

Apabila syarat untuk $\lambda_{2}$ terpenuhi maka nilai untuk $\lambda_{3}$ juga pasti terpenuhi. Hal ini dikarenakan bila $-B+\sqrt{B^{2}-4 A C}<0$ maka nilai dari $-B-\sqrt{B^{2}-4 A C}$ juga kurang dari nol.

Dengan stabilnya nilai eigen (4.2), nilai eigen (4.1) akan menjadi tidak stabil. Dapat dilihat (4.2) akan stabil jika memenuhi syarat $L>0 \quad$ atau $\quad x>\mu+\mu_{t}+y \quad$ yang menyebabkan nilai eigen (4.1) menjadi positif dan tidak stabil. Dapat dikatakan titik kritis (1) stabil maka titik kritis (2) akan menjadi tidak stabil, begitu pula sebaliknya.

\section{Basic Reproduction Ratio $\left(\boldsymbol{R}_{\mathbf{0}}\right)$}

Di dalam epidemiologi, tingkat penyebaran suatu penyakit menular biasa diukur dengan suatu nilai yang disebut basic reproduction ratio $\left(R_{0}\right)$. Karena pada titik kritis terlihat suatu kondisi disease-free equilibrium, maka $R_{0}$ dapat dicari. Agar terbebas dari penyakit campak, harus dibuat $R_{0}<1$. Dalam hal ini setiap penderita hanya dapat menyebarkan penyakit kepada rata-rata kurang dari satu penderita baru, sehingga pada akhirnya penyakit akan hilang. Sedangkan, apabila $R_{0}>$ 1 maka setiap penderita dapat menyebarkan penyakit kepada rata-rata lebih dari satu penderita baru, sehingga pada akhirnya akan terjadi epidemik.

Untuk mencari $R_{0}$, karena yang ingin dikendalikan adalah populasi yang menyebarkan penyakit campak maka hanya diperlukan model $I$ pada persamaan pada (4.1). Misalkan $A$ adalah turunan dari $\frac{d I}{d t}$ terhadap $I$, dimana $A=M-D$. Dengan demikian dapat diketahui $R_{0}=M D^{-1}$. Sehingga diperoleh:

$$
A=\frac{x S}{N}-\frac{x S I}{N^{2}}-\left(\mu+\mu_{t}+y\right)
$$

Substitusikan titik kritis $\left(S=\frac{\Pi}{\mu}, I=0, R=0\right)$ pada (4.4), sehingga:

$$
A=x-\left(\mu+\mu_{t}+y\right)
$$

Dari persamaan di atas dapat diketahui $M=x$ dan $D=\mu+\mu_{t}+y$. Dari sini diperoleh:

$$
\begin{gathered}
R_{0}=M D^{-1} \\
R_{0}=\frac{x}{\left(\mu+\mu_{t}+y\right)}
\end{gathered}
$$

$R_{0}<1$ terjadi apabila $x<\mu+\mu_{t}+y$ sedangkan $R_{0}>1$ terjadi apabila $x>\mu+\mu_{t}+$ $y$. Kondisi ini akan sesuai dengan analisis parameter terhadap titik kritis dan nilai eigen pada pembahasan sebelumnya, yaitu kondisi jika titik kritis (1) stabil maka $R_{0}<1$, sedangkan jika titik kritis (2) stabil maka $R_{0}>1$.

Berdasarkan hasil $R_{0}$ yang diperoleh, untuk membuat $R_{0}<1$, penyebut harus lebih besar dari pada pembilang. Kematian karena faktor lain $(\mu)$ dan kematian karena campak $\left(\mu_{t}\right)$ tidak dapat ditingkatkan. Oleh karena itu yang perlu dilakukan adalah penyembuhan atau pengobatan bagi penderita campak, sehingga laju kesembuhan $(y)$ akan meningkat. Selain itu laju penularan penyakit campak $(y)$ juga harus diturunkan, dengan demikian tingkat penyebaran penyakit campak akan berkurang sehingga penyakit lebih dapat dikendalikan dari keadaan epidemi. Jadi dapat dikatakan, dari 
analisis ini akan diketahui parameter yang paling berpengaruh dari semua parameter yang ada dalam model penyebaran penyakit campak adalah parameter $x$ dan $y$.

\section{Simulasi Analisis Numerik}

Untuk menguji analisis di atas, diberikan dua buah kasus yaitu kondisi saat $R_{0}<1$ dan kondisi saat $R_{0}>1$.

1. Simulasi untuk $\boldsymbol{R}_{\mathbf{0}}<1$.

Berdasarkan syarat agar $R_{0}<1$, maka dimisalkan parameter sebagai berikut:

$\Pi=500$,

$b=0,00015$,

$c=0,027$,

$\mu=0,0009$,

$\mu_{t}=0,0001$

Substitusikan parameter (4.5) ke titik kritis pada perhitungan di atas, sehingga diperoleh titik kritis sebagai berikut:

1. $\left(S=5.5555556 \times 10^{5}, I=0, R=0\right)$, dan

2. $\left(S=3.1 \times 10^{8}, I=-9.9464286 \times 10^{6}\right.$, $\left.R=-2.9839286 \times 10^{8}\right)$.

Titik kritis (2) dapat diabaikan karena populasi bernilai negatif. Ini berarti hanya digunakan satu titik kritis yaitu titik kritis (1) yang memberikan disease-free-equilibrium.

Nilai eigen dapat ditemukan dengan mensubstitusikan parameter yang didapat ke nilai eigen (4.2) dan (4.3), sehingga didapat nilai eigen sebagai berikut:

1. Untuk titik kritis (1), $\lambda_{1}=-0.0009, \lambda_{2}=$ $-0.0009, \lambda_{3}=-0.02785$.

2. Untuk titik kritis (2), $\lambda_{1}=0.0028949$, $\lambda_{2}=-0.0009, \lambda_{3}=-0.0028965$.

Dapat dilihat nilai eigen yang stabil adalah nilai eigen untuk titik kritis (1), ini berarti sistem akan menuju ke titik kritis $(S=$ $\left.5.5555556 \times 10^{5} I=0, R=0\right)$. Hal ini merupakan kondisi yang diharapkan karena akan menuju kondisi yang bebas penyakit campak.

Dengan metode Runge-Kutta orde 4 akan diperoleh perilaku dinamik dari sistem yang terbentuk di atas dan dalam simulasi ini menggunakan nilai awal: $S(0)=400000$, $I(0)=50000, R(0)=250000, N=S+I+$ $R=700000$, dan nilai $h=1$, dengan $t$ dalam bulan, sehingga dengan demikian diperoleh Gambar 4.2:

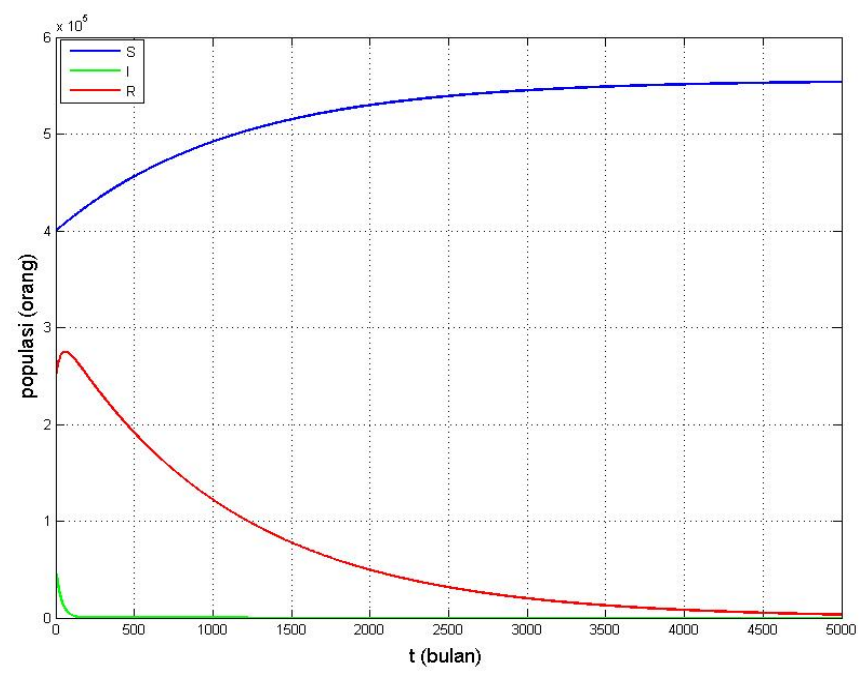

Gambar 4.2 Grafik Simulasi untuk $R_{0}<1$

Gambar 4.2 menunujukkan perubahan jumlah populasi $S, I$, dan $R$ terhadap waktu. Terlihat bahwa populasi $I$ dan $R$ akan mengalami penurunan dan akan menuju nol, sedangkan populasi $S$ akan mengalami peningkatan. Hal ini berarti jika parameter yang terbentuk memenuhi syarat $R_{0}<1$ maka penyakit campak akan dapat dikendalikan.

\section{Simulasi untuk $\boldsymbol{R}_{\mathbf{0}}>1$.}

Diberikan parameter yang memenuhi syarat agar $R_{0}>1$ sebagai berikut:

$$
\begin{aligned}
& \Pi=500, \\
& b=0,0097, \\
& c=0,00032,
\end{aligned}
$$

$\mu=0,0009$,

$\mu_{t}=0,0001$.

Titik kritis diperoleh dengan mensubstitusikan parameter (4.6) ke titik kritis pada perhitungan di atas sehingga titik kritis menjadi:

1. $\left(S=5.5555556 \times 10^{5}, I=0, R=0\right)$, dan

2. $(S=70601.85185, I=3.3065025 \times$ $\left.10^{5}, R=1.1756453 \times 10^{5}\right)$.

Dengan mensubstitusikan parameter ke nilai eigen (4.2) dan (4.3), diperoleh nilai eigen sebagai berikut:

1. Untuk titik kritis (1), $\lambda_{1}=-0.0009, \lambda_{2}=$ $-0.0009, \lambda_{3}=0.00838$

2. Untuk titik kritis (2), $\lambda_{1}=-0.0056534$, $\lambda_{2}=-0.0014285, \lambda_{3}=-0.0009$.

Nilai eigen yang stabil adalah nilai eigen untuk titik kritis (2), ini berarti sistem akan menuju ke 
titik kritis $(S=70601.85185, I=$ $\left.3.3065025 \times 10^{5}, R=1.1756453 \times 10^{5}\right)$.

Dengan metode Runge-Kutta orde 4 akan disimulasikan menggunakan nilai awal: $S(0)=$ $400000, I(0)=50000, R(0)=250000, N=$ $S+I+R=700000$, dan nilai $h=1$, dengan $t$ dalam bulan:

\section{KESIMPULAN}

Model matematika untuk penyebaran penyakit campak dilakukan dengan empat tahapan. Pertama, perlu melakukan identifikasi masalah agar dapat menentukan sub populasi yang akan digunakan dalam model. Kedua, membuat asumsi terhadap faktor-faktor yang memengaruhi penyebaran penyakit campak. Ketiga, menganalisis parameter dari model yang telah terbentuk. Keempat, melakukan simulasi untuk menguji hasil analisis parameter.

Dengan menganalisis model matematika yang terbentuk, dapat dilihat parameter yang berpengaruh paling signifikan dalam penyebaran penyakit campak adalah laju penularan penyakit $(x)$ dan laju kesembuhan $(y)$. Parameter lain yaitu laju kematian karena faktor lain $(\mu)$, kematian karena penyakit campak $\left(\mu_{t}\right)$, dan kelahiran penduduk $(\Pi)$ tidak dapat diubah, karena parameter tersebut terjadi secara alami dalam kehidupan nyata.

\section{DAFTAR PUSTAKA}

[1] Alodokter. 2016. Campak. http://www.alodokter.com/campak. Diakses 1 Juni 2017

[2] Castillo, Carlos., Chavez, Z. Feng, and W. Huang. 2002. "On the Computation of $R_{0}$ and Its Role on Global Stability”. In Mathematical approaches for emerging and reemerging infection diseases: an introduction, 57, 831-835

[3] Diekmann, O. and J.A.P. Heesterbeek. 2000. Mathematical Epidemiologi of Infectious Diseases: Model Bulding, Analysis and Interpretation. Simon Levis, Princeton University, USA

[4] Fredlina, K. Queena., Tjokorda Bagus Oka, dan I M.Eka Dwipayana. 2012. "Model SIR (Suspectible, Infectious, Recovered) untuk Penyebaran Penyakit Tuberkulosis". E-Jurnal Matematika, 1(1), 52-58

[5] Mathews, John H and Kurtis K Fink. 2004. Numerical Methods Using Matlab. Fourth Edition. Upper Saddle River, New Jersey, USA
[6] Muhdor, Ach. 2007. "Model Matematika pada Radang Akut dengan Sistem Persamaan Diferensial”. Skripsi. Universitas Islam Negeri Malang. $\quad$ http://lib.uinmalang.ac.id/fullchapter/03510028.pdf . Diakses 9 April 2011

[7] Purcell, E.J, D. Varberg and S.E. Rigdon. 2004. Kalkulus Jilid 2. Terjemahan. Edisi Kedelapan. Penerbit Erlangga. Jakarta

[8] Purwanto, Heri, G. Indriani dan E. Dayanti. 2005. Aljabar Linier. PT Ercontara Rajawali. Jakarta

[9] Scheid, Francis. 1992. Analisis Numerik. Terjemahan. Cetakan Kedua. Penerbit Erlangga. Jakarta

[10] Soleh, Mohammad., Siti Rahma. 2012. "Model SEIR Campak dengan Vaksinasi dan Migrasi”. Jurnal Sains, Teknologi dan Industri. 9 (2). 113 123

[11] Waluya, Budi. 2006. "Persamaan Diferensial". Buku Ajar http://uuniquee.files. wordpress.com/ 2010/09/persamaan_differensial_-_dr_st-budi_waluya.pdf. Diakses 12 Juni 2017

[12] Wikipedia. $2017 . \quad$ Campak. https://id.wikipedia.org/ wiki/Campak. Diakses 1 Juni 2017 